\title{
"Even if a sparrow is small, it still has all organs". Chinese and Greenlandic Gendered Perspectives on the Global Arctic.
}

\author{
Hanne Petersen ${ }^{1}$ \\ Center for European and Comparative Legal Studies, University of \\ Copenhagen, Denmark
}

\begin{abstract}
This essay is an attempt to bring together experiences and research by the author related to the fields of gender, the Arctic, especially Greenland, and China. Comparison of these very divergent and different parts of the world in scale, population and size of the economy as well as legal and normative cultures is hardly possible. Nonetheless a gendered - and personal - perspective reveal similarities in development especially in relation to rapid social change, urbanization, globalization and climate and environmental challenges. The use of the essay as a genre has seemed to me particularly apt for this purpose of looking for links and similarities.
\end{abstract}

Keywords: Similarities, myth, environment, fears and dreams

\footnotetext{
${ }^{1}$ Corresponding author. Address: Hanne Petersen, Professor of legal cultures, CECS, Center for European and Comparative Legal Studies, Karen Blixens Plads 16, 2300 Copenhagen S, Denmark.

E-mail: Hanne.Petersen@jur.ku.dk
} 
All deep sowing, as the Taoists said, is in empty space. And all sowing makes us tremble... When Electra thought she'd given birth to a dragon, she saw that the monster was crying to be nursed; she gives it her breast without hesitation and the milk comes out mixed with blood. Even though she had given birth to a monster, something which must have disconcerted her, she knew that her response had to be to keep it from dying of hunger, because the greatness of man consists in his ability to assimilate what's unknown to him. To assimilate in depth is to give an answer. (Jose Lezama Lima: Paradiso 1968/2000, 247).

\section{Prelude - on Changes, Ways and Links}

One of the most important Taoist books is I Ching or book of changes, which was published in a quite famous German translation in 1924 by a German sinologist, theologian and missionary, Richard Wilhelm. In 1992 I acquired a version rendered into English of this book, and brought it with me to the European University Institute in Florence in Italy, where I spent the year of 1993-94 as a Jean Monnet Fellow-with time to study the overwhelming artistic heritage of the city-and time to read the I Ching from beginning to end. Having first visited China as a member of a group of Danish lawyers in 1979, I had become interested in Chinese culture and civilization. Perhaps because of the recent end of the Cold War I was fascinated by the focus of the IChing on the constancy and permanence of change. Another attraction was the unfamiliar and to me peculiar approach of a clearly normative book, which focused upon how to solve dilemmas and difficult questions formulated by the user of the book. These questions were to be answered by way of an accidental but procedurally organized selection of a section of the text, which would include an image and its connected interpretation. This random section would thus provide an 'answer' to the question posed. It is described as an ancient book of divination (more than two and a half millennia) used amongst others for moral and practical guidance.

I grew up as not quite a foreigner (belonging to a Danish minority) in a country which no longer exists (Western Germany) in a century and era long gone (post-World War II and the Cold War). It was characterized by gender identities, which are no longer as irreconcilable as they seemed to be then - however, they have since been replaced to some extent by other contested identities since. I thus belong to the many, who have experienced waves of change as part of everyday life over more than half a century. The reverence of a past stability and harmony goes hand in hand with major and sometimes monstrous changes. In 1994 my informal mentor, professor Agnete Weis Bentzon (1918-2013), a lawyer and woman, who had gone on the Legal Expedition to Greenland in 1948-49 with her husband, Jewish 
lawyer Verner Goldschmidt (see Petersen 2014a), suggested to her second husband that he might ask me (and my husband) if we would be interested in moving to Greenland to work there. The miniscule University of Greenland in Nuuk suffered from internal conflicts as had often been the case, and was in need of a teacher and professor - preferably in economy. They were however in short supply in Denmark and not necessarily motivated to leave for arctic mixed economies. With my interest in legal pluralism-and women's law-Agnete expected that I might be interested. I was-but I was also highly insecure about what moving to "the end of the world" would imply.

I brought the I Ching with me to Greenland, and I now began consulting it "properly" by way of "random" references on several occasions, where I encountered situations, conflicts and dilemmas, which I was not sure how to handle, and where I had a clear sense that my formal education and former experiences would not necessarily be very helpful. I was oftentimes surprised to observe how helpful and valuable its outlandish language and archaic images were in opening up for unexpected and imaginative interpretations of concrete situations. Before going to Greenland I had spent almost two decades dealing with women's law and feminist issues. While in Florence I had rewritten my Danish dissertation on informal law into a book in English, and due to my transfer to the Arctic and Greenland I ended up calling it Home Knitted Law. Norms and Values in Gendered Rule-Making (1996). At that time it was not easy to find a publisher for a book of such non-black letter nature. But after 1989 things were gradually changing and I managed.

Coming to Greenland in 1995-and living and working there until 1999-I experienced a peculiar situation regarding my earlier involvement in gender and law. Here I was-a privileged female white professor of lawrepresentative of a field of knowledge of limited or ambivalent value in a post-colonial society ruled by Home Rule authorities since 1979. For my students it took a short while to overcome the ambivalence against yet another foreigner suffering from culture shock in the Arctic. For me it took some time to adjust and assimilate my experience and knowledge to something useful in a context, which for me was in several ways quite unfamiliar. The delight of encountering a group of (primarily female) students and of developing a mutual interest in each other's knowledge turned out to become a gift. After a considerable period, I realized that I could not just transfer my Nordic and European experiences and views on gender relations, norms and legality from primarily agricultural and industrial legal cultures to a post-nomadic society. Here to some extent, a tradition of gender complementarity (had) prevailed and women's work 
and participation had always been a condition for survival of families and communities.

In 1998, the Danish Ministry of Foreign Affairs asked if I was interested in going to China for a weeklong seminar with Chinese and EU participants on Women's Human Rights. The "real" meeting on Human Rights had taken place the week before in Beijing. It was only five years after the acknowledgment at the Vienna Human Rights Conference that women's rights were also human rights and only three years after the big UN conference on Women in Beijing in 1995. The West was openly acknowledging its considerable interests in trading with and investments in China about a decade after the Tien An Men "event" as it is now called in China. Things were returning to "normal" in the Western-Chinese relations. In the lobby of the hotel, where the delegation I was part of stayed, a lot of primarily American couples were meeting and "collecting" Chinese girls, which due to the One Child Policy (policy! not law) initiated from 1979, had been given up for adoption. This practice has since been abandoned, as has recently also the One Child Policy. During the One Child Policy (and perhaps also now) Chinese parents and hospitals practiced "voluntary" and "forced" sex selective abortions in high numbers due to explicit economic sanctions following a second - now third - pregnancy and child in China. Greenland has seen very high percentages of abortions, maybe due to implicit economic pressures combined with more relaxed sexual mores and a high traditional value of children in some parts of society (Bjerregaard ed, 2001). Present Danish abortion law allows for abortions due to potential present or future handicaps of the child. A large majority of the Danish population generally supports this.

My Greenlandic students convinced me to go to China in 1998-and told me "to talk about us". That taught me that in world society everybody is a minority, although of course a country with a population of 1.4 billion people is a highly significant minority. In 2015 a young male Chinese lawyer taught me a Chinese saying "even if a sparrow is small, it has all organs". It seemed like a good description of the viability of the small communities of the world. Now that the ice cap in the Arctic is melting, we are again learning that the species are interrelated. The melting ice cap is opening up the North West and North East Passages allowing for risky sea travel and shorter sea routes between China and Europe. Higher sea levels may influence the limited arable land for the world's big Chinese minority, which comprises $20 \%$ of the world's population but has only $8 \%$ of arable land.

After stopping to work intensely with Greenland from 2006, I was asked to do work on gender, law and religion in the Mediterranean and Middle East with its indispensable energy resources upholding increasingly unsustainable lifestyles and its contagious and explosive mix of religion, 
law, gender conservatism and neo-liberal economies. Following a longer visit to China in 2009 for the conference on international philosophy of law - on Global Harmony and Rule of Law - I published an article on comparisons of global legal cultures including Chinese legal culture (Petersen 2011). In the summer of 2012 the then president of China, Hu Jintao visited Denmark - the first state visit ever since the establishment of the PRC. Expectations for Danish market opportunities in the huge Chinese market were massive. Other Chinese ministers already had paid visits to Greenland a few months earlier, and at the end of 2012 I was contacted by young Chinese lawyer working in a major Danish (business) law firm particularly focusing on Chinese investments in resource extraction in Greenland/Denmark and Danish investments in China. Together we taught the first course at the University of Copenhagen on Chinese legal culture and business law in the fall of 2014. In the spring of 2015, I went on two research trips to Greenland and China respectively primarily financed by the Sino-Danish Center.

On June $2^{\text {nd }} 2015$ I returned to Copenhagen to be able to participate in the celebrations on Constitution Day, June 5, on the occasion of the 100 years anniversary of the voting rights granted to Danish women-and men without their own households. During World War I in 1915 women, the poor, and the dependent males - but not Greenlandic men and women - were granted voting rights. They had to wait for constitutional changes in 1953 before they got voting rights for the parliament of the Danish Kingdom. In 1949 Greenlandic women had been granted voting rights for local elections, several years later than Greenlandic men. Chinese women were granted voting rights with the enactment of the constitution of the People's Republic of China from 1954 - but they have had little opportunity to participate in free elections in the period ever since. Denmark had to wait for its first female prime minister ever until 2011. Helle Thorning-Schmidt led a centre left coalition government, where female chairs initially led all the parties. She managed to celebrate the centenary for women's vote but her coalition lasted only one term, as it lost the elections very narrowly on June 18, 2015. A new minority government supported by three small centre right parties all led by male leaders took over ten days later. Voters at this election were divided along gender lines and according to educational levels and urban/rural lines to an up till then unseen degree.

\section{On Voices and Votes}

Blackbirds are small birds with strong voices. They select a high position especially in the morning and evening at sunrise and sunset to be sure to have an overview and to be heard. Their vistas may not be democratic, and they will have no votes-but sometimes they will be heard-and loved- 
nonetheless. In Greenland the "snow sparrow" is the most common Greenlandic bird. One to ten million couples breed in the summer before the birds on the West coast migrate to North America and those on the East coast to Siberia during the winter. These migratory routes also indicate the geostrategic and geopolitical position of Greenland between the two big powers of the $20^{\text {th }}$ Century, the United States and the Soviet Union, which has been of importance for the status of this society for a considerable period. The geopolitical landscape has been changing after the collapse of the Soviet Union, as has the importance of the poles for global society. Population density in the Arctic is low and the Greenlandic community of humans is indeed a small one, about 56,000 people, of whom 85 percent are indigenous. 48,000 of the population now live in towns, and about 16,000 in the capital of Nuuk. Percentagewise this demonstrates the global tendencies of urbanization as everywhere else in the world. Greenland experiences other global tendencies such as increasing demand for resources as well as the impact of climate change. The Arctic is becoming the global Arctic.

China is the new player in the global geopolitical landscape and has long had interests in the Antarctic, but from the $21^{\text {st }}$ Century, its interest in the Arctic has been growing (on global change and geopolitics see Smith 2012, McCoy 2015 and Moïsi 2009). As a "near Arctic State" it was vying for status as an observer state in the Arctic Council (established in 1997) at a meeting in 2009, and gained status as permanent observer in 2013 with rights to voice the Chinese perspective, but without voting rights. The doors for the global hunters of resources-including China-had already been opened in Greenland. Chinese interests in an iron mine in Isua, had been well known for several years. Greenland has some of the world's biggest deposits of rare earth elements, used in communication technologies. These are strategically important metals in which China has a near monopoly. Former Premier Hans Enoksen visited China in 2005 followed by a number of later Home and Self Rule ministers. China's Minister for Land and Resources $\mathrm{Xu}$ Shaoshi visited Greenland in April 2012. In September 2012, South Korean President Lee Myung-bak's visit to Greenland showed that China was not the only Asian power to look at Greenland (Degeorges 2013).

These Asian visits and the Greenlandic preparations for legislations on investments which would possibly imply import of a couple of thousand Chinese male mining workers gave rise to hope for a more self-sufficient economy in Greenland, perhaps leading to full independence. It also arose fear of loss of influence over Greenland in Denmark-and probably also a less explicitly voiced fear of loss of influence of a minimized Denmark in world society. The geopolitical aspects of the Asian interests in the Arctic are probably a sign of a changing geopolitical landscape after the end of the Cold 
War and the financial crisis, which hit especially Iceland very fast and hard, while Greenland was hit somewhat later. The Greek economic drama in the Mediterranean also illustrates aspects of the growing global interests and investments of China.

What are the gendered consequences of such geopolitical shifts and changes? The present period is witness to refugee movements of a scale not experienced since the end of World War II, which also raises issues of gender. Especially young men embark on long and dangerous journeys, while women seem to move more readily from the countryside to urbanized areas in many parts of the world for education, paid work and better living conditions - including in Greenland and China.

In early May 2013, elections in Greenland led to one such woman becoming the first female prime minister in Greenland. Aleqa Hammond was born 1965 in Southern Greenland. She grew up in Northern Greenland as a daughter of a hunter. Her father died, when she was very young, she traveled the world and was educated amongst others in Canada. She had been a member of the Greenlandic leading party, Siumut, and became a member of government from 2005. Her charismatic personality and highly controversial and populist leadership style divided the population. She declared as her dream and one of her important goals that Greenland would become an independent nation acknowledged by the UN. One of the tools for this goal was increased authority over and exploitation of mineral resources in Greenland including "rare earth". The coalition government formed after the May elections had decided to lift the ban on exploitation of uranium resources in Southern Greenland as part of their foundation. After long debates in Inatsisartut, the Greenlandic Parliament, at the end of October 2013 a narrow majority of 15 votes against 14 decided to abandon the zero tolerance policy on uranium mining, which first the Home Rule government and from 2009 the Self Rule government had inherited from Denmark. This was a very controversial decision, which gave rise to several demonstrations in Greenlandic cities, especially in Southern Greenland, where the uranium resources exist. It gave rise to internal conflicts in Greenland and amongst Greenlanders-as well as in relation to Denmark, which had already been alarmed at the prospects of "large scale" Chinese investments in Greenland. After a corruption scandal, Aleqa Hammond resigned in October 2014 as leader of the Greenlandic government, and new elections took place. In 2015 she was elected as one of the two Greenlandic members of the Danish parliament.

One of the strong voices to rise after the uranium decision was that of a young female Greenlandic artist, Bolatta Silis Høegh, born in 1981 in Qaqortoq, Southern Greenland, close to the mountain, Kvanefjeldet, where uranium was to be mined. Bolatta Silis Høegh is the daughter of the most 
well-known Greenlandic national artist Aka Høegh. Her father, Ivars Silis, is initially from Latvia and originally trained as an engineer. He moved first to Denmark and then on to Greenland to work amongst others with nature photography. Bolatta has been living in Denmark for several years, but still has strong family ties to Greenland. In several interviews she mentioned her severe physical reactions to the decision to lift the ban on uranium mining in 2013. She felt sick for several days as if from a strong hangover or headache. Then she got up and painted a series of dramatic oil paintings called Lights On Lights Off (Nordlund 2014; Schultz-Lorenzen 2014; Vahl 2014)). She exhibited the series of paintings in a run-down place in Copenhagen (a former royal apartment used for hunting trips) in August 2014. Seeing them reminded me of Goya's Black Paintings painted between 1819 and 1823. Both series portray intense, haunting themes. Bolatta uses her own naked body in stark paintings, one of them with the bloody head of a horse replacing her own. The injured bodies and the dark ominous landscapes in her paintings both reflect violence, death, and a fear of the consequences of the political decision, as well as repressed emotions related to experiences of brutal deadly events in her childhood in the small and in some ways idyllic city, where she grew up. She told that some Greenlanders had condemned her for her critique of the uranium policyalso because she did not live in Greenland, and thus was not entitled to voice a criticism. Violence and tragedy are part of recent history in both Greenland and China not to speak of Europe in the $20^{\text {th }}$ century. Traumas and taboos are linked, and are only sometimes given voices. As for instance in the Greek and Greenlandic myths-and probably also in Chinese myths and sayings.

After the Danish elections on June 18, 2015 a completely new party, Alternativet [The Alternative] was voted into the Danish Parliament, much to the surprise of most political commentators. The party is led by an openly gay long time local politician, who served as a minister of culture for a short period after 2011, but chose to step down, when he was accused of corruption in 2013 due to a number of representative activities by the ministry carried out at the institution, where his partner was employed. The accusations were later refused. Even if the press considered the party a bunch of frivolous performers not to be taken seriously, Alternativet managed to mobilize a considerable number of young people and its 10 point program listed the following priorities: a sustainable society; an entrepreneurial society; a safe society; a holistic society; a practical society; a wild society; a reflective society; a curious society; a vital society; a society of equal worth. Only three out of the nine elected candidates for the parliament (with 179 seats) were women. A fourth woman ran for election but was not elected. She was also the only candidate with an immigrant 
background from a part of Copenhagen, with a high number of immigrants, where the party received an extraordinarily high number of votes. In the public debate the party is primarily identified with a focus on transition to a sustainable society.

\section{"Under the Dome"}

On February 28, 2015-on the Saturday preceding the meetings of the National People's Congress and Chinese People's Political Consultative Conference-a female Chinese journalist, Chai Jing, who had earlier worked for Chinese State Television (CCTV) for a decade released a 104-minute long video called Under the Dome. The film dealt especially with air pollution in China and particularly in Beijing. It was initially streamed on major internet platforms without interference from censors, and it was accessible on the Internet for about a week. According to different sources it drew around 200-300 million views within this period. After it was censored, it was removed to less accessible platforms (see Fearon 2015, Fox-Learner 2015).

Chai Jing had traveled to the US to give birth to her daughter in October 2013, and this led to an outrage among Chinese netizens, who branded her as a 'birth tourist'. In the video, she tells that she learned that her daughter had a tumor, and had to undergo an operation. She feared the tumor might be due to air pollution, and following her daughter's birth and operation, she undertook a yearlong self-financed investigation following up on some of her earlier work as an investigative journalist. She explains in the video how she had never cared about air pollution before she got pregnant and had never worn a mask. After she became pregnant, she became much more concerned with these issues. I had only managed to see a little bit in Chinese before my visit to China in April and May 2015. However, a group of young Chinese high school students quickly got together to produce English subtitles for non-Chinese audiences. The video has since been available in sections on YouTube (https://www.youtube.com/watch?v=MhIZ50HKIp0). During my visit to China, I gave a couple of lectures to Chinese students, and I asked them if they had seen the video. In a small Human Rights class in a Beijing University where the professor was not present, everybody had seen it. In a class of demography students at another Beijing University, where the professor was present hardly anybody but the professor admitted to have seen it. In a big class of master students of law at a University in Shanghai, where the teacher of the class was not present only a couple of students had seen it. In one of the Beijing classes a young student, who I later learned was also a party member, criticized Chai Jing for being rich

\footnotetext{
${ }^{2}$ The sources for this section are my own interviews and the videos. I have on purpose kept the interviewees in the whole article anonymous.
} 
and out of tune with popular concerns and needs for growth. A professor who had worked with victims of pollution for several years told that the validity of the data in the video had been questioned by the powerful coal and oil industries, which Chai Jing criticizes severely in the film.

The video displays the difficult balance between economic development and environmental protection which was also at stake in the Greenlandic change of policy on uranium exploitation. But even more it demonstrates the strengths and weaknesses of the environmental bureaucracy and the lack of coordination, which leads to a considerable distrust in public and party authority especially in China. A frustrated environmental bureaucrat at some point says that "the Environmental Protection Bureau is like a cat raised by the government. Our ability to catch mice and the number we catch is determined by the government." The air pollution is produced both by factories and by transportation including trucks with counterfeit certificates. Coal accounts for 70 percent of total energy consumption in China and quality standards of fuel are dictated by the petrochemical industry. The whole energy sector is fraught with corruption. In the video the present president Xi Jinping is quoted for saying that, "the dignity of law lies in its execution." Only one percent of environmental disputes in China reach the courts according to the video. Even if one of the well-known Chinese environmental activists in the film claims "We have the right to know, the right to participate and the right to justice", and Chai Jing finishes saying that "We have no right to consume without self-control. We have no right to complain without building anew", she also concludes, "Government can't solve pollution on its own. It must rely on ordinary citizens like you and me. On our choices. On our determination... information transparency is necessary for public participation." In a One Party state practicing political censorship Chai Jing has demonstrated that it is possible to have a very powerful voice. As in the case of Bolatta Silis Høegh, hers is not a democratic voice nor a voice in a democracy. Theirs are strong and concerned voice, which express worries and fears shared by many.

\section{"Unprecedented materialistic advancement" and "an atmosphere of hypocrisy"?}

When the American poet Walt Whitman (1819-1892) wrote his Democratic Vistas in 1871 few countries in the world were democracies, and many cared little about the welfare of their populations:

For my part, I would alarm and caution even the political and business reader, and to the utmost extent, against the prevailing delusion that the establishment of free political institutions, and 
plentiful intellectual smartness, with general good order, physical plenty, industry, \&c., (desirable and precious advantages as they all are,) do, of themselves, determine and yield to our experiment of democracy the fruitage of success. With such advantages at present fully, or almost fully, possess'd - the Union just issued, victorious, from the struggle with the only foes it need ever fear, (namely, those within itself, the interior ones,) and with unprecedented materialistic advancement - society, in these States, is canker'd, crude, superstitious, and rotten. Political, or law-made society is, and private, or voluntary society, is also. In any vigor, the element of the moral conscience, the most important, the verteber to State or man, seems to me either entirely lacking, or seriously enfeebled or ungrown.

I say we had best look our times and lands searchingly in the face, like a physician diagnosing some deep disease. Never was there, perhaps, more hollowness at heart than at present, and here in the United States. Genuine belief seems to have left us. The underlying principles of the States are not honestly believ'd in, (for all this hectic glow, and these melodramatic screamings,) nor is humanity itself believ'd in. What penetrating eye does not everywhere see through the mask? The spectacle is appalling. We live in an atmosphere of hypocrisy throughout. The men believe not in the women, nor the women in the men. A scornful superciliousness rules in literature. (Whitman 1871 - see also Petersen 2014b).

This could almost describe the present situation in China - and to some extent in the Arctic and Greenland. Whitman wrote this essay during the period Mark Twain called "the gilded age". Writer Evan Osnos, who lived in China for more than a decade compares the Chinese development after the 1990s with this gilded age in his book "The Age of Ambition" (Osnos 2014). After Mao's death in 1976 Deng Xiao Peng started a period of considerable and far reaching economic reform in China, which has led to unprecedented growth rates in the Chinese economy. This "growth fetish" has so far kept the population content, but that may not go on forever (Petersen 2015). A young well-educated Chinese woman told me after a long conversation that "obsessive materialism can no longer give meaning to people." In Greenland, a period and process of considerable political reform started from the mid-1970s, which first led to Home Rule in 1979 and later to SelfRule from 2009. Both Chinese and Greenlandic processes were driven by strong ambitions and strong hopes for quick and easy fortunes, and both were probably skewed. Perhaps due to its geopolitical importance to Denmark there was limited interest and little emphasis in both Denmark and Greenland on economic reforms in Greenland. The strong interest of the 
One Party State to continue its hegemony, has given little leeway and motivation for political reform in China. Double standards are strong in China where "core socialist values" are expected to coexist with market principles. And double standards are perhaps also at stake in a Greenlandic society, where political leaders announce a goal of political independence, while politically and economically they are not able and/or willing to break a paternalistic relation to the former colonial power.

The level of trust is generally quite low in China, perhaps also in gender relations. In Greenland a certain watchfulness exists towards especially highly educated bilingual Greenlandic women, both societies-different as they are-having in common that developments since 1979 have led to a skewed gender balance. In Greenland and in the Arctic in general this is due to increased immigration of primarily male labour with higher and more specific qualifications than the local (male) labour force. A Danish poet in 1980 described this as a situation of "The three genders": Greenlandic women, Danish men and Greenlandic men-the last group was almost described as "left-over men" (Sven Holm in Arnfred 1991). In China the combination of a One Child Policy and an opening up towards market forces has led to a situation, where the son preference, which can be found in most patriarchal societies in the world has led to more boys being wanted and born than girls. Female fetuses may be aborted by early "voluntary" sex selective abortions following prenatal tests to determine sex even if these tests are not legal. If couples do not have the economic means to pay for an extra child, the woman may be forced to perform an abortion. Kay Schaffer and Sidonie Smith (2014) describe a case where such a forced abortion went viral giving rise to a pressure on the state to compensate the woman forced to abort. In Greenland abortion figures have been very high since abortion was legalized in 1973, and more pregnancies end in abortions than with the birth of children. This has been explained as a situation, where abortion has become a widespread form of contraception (Bjerregaard 2001). The reasons may be combinations of a high number of 'unwanted' pregnancies (owing to economic conditions and needs to finalize educations) in a society which values the status of children and grandchildren highly, and which is characterized by a lifestyle, where contraceptive practices are relaxed also amongst women, and where alcohol consumption is widespread. It is also well known that fertility rates drop in many countries, when economic conditions deteriorate. This was particularly clear in the post-communist states in Europe after 1989, and has also been noticed in Denmark after the financial crisis.

In traditional Chinese society the son was the one to carry on the family name and to take responsibility for securing the welfare of old age parentssomething which has again become important in a de facto market society. 
Post 1979-China has witnessed a reintroduction of Confucian hierarchical values and one of the consequences has been a reintroduction of a (re)traditionalized gender hierarchy. Women with high educations are not expected to want to or be able to adapt to this gender hierarchy. Such women have been considered unmarriageable and they are described as "left-over women". At the same time fewer women in shorter supply for marriage has led to a rise in the economic demands for future male spouses. Chinese middle class men (and their parents) now have to provide wellfurnished expensive apartments and cars to be considered as interesting suitors. All over the world women have got easier access to (higher) education during the last part of the $20^{\text {th }}$ century. This has allowed them to access some of the privileges related to education, which has for hundreds of years been a monopoly of the male (elite) parts of societies worldwide. In Greenland it means that bilingual women with higher education have moved with relative ease from the old society to the new-"repressed and sought after in both" (Holm in Arnfred 1991). Given the gender and ethnic composition of Greenlandic society, ethnically mixed marriages may often mean that Greenlandic women marrying non-Greenlandic husbands may be economically and materially better off. Not everybody is benefitting from the 'unprecedented materialistic advancements' in a world, which has also witnessed increasing economic disparities over the last several decades in the Arctic as well as in Asia.

During my visit to Beijing I went to see a modern Chinese drama, which I chose because of its intriguing (bilingual) title. It was called "I hate therefore I marry." I relied on my earlier experiences from Florence and Greenland, which had taught me that 70 per cent of all communication was non-verbal, and thus hoped to make sense of this play. The audience was full of young women, and the actors conveyed strong tensions and depressive moods. The description of the play in the internet version of Global Times (a newspaper close to the Communist Party) was as follows:

If you're Chinese and in your mid-20s, there's a certain question you're bound to start hearing with increasing frequency from parents, extended family and even friends: "So, when are you going to get married?" This phenomenon has come under the spotlight in recent years with the rise in popularity of matchmaking TV programs and pejorative terms such as "leftover women." All this is indicative of the truth that, in China, marriage is not a personal thing between two people, but a social concern that puts huge pressure on not only young people but also their parents and relatives. This phenomenon gave Edward Lam, the famous Hong Kong theater director and writer who has 55 productions under his belt, the inspiration for his new work I Hate Therefore I Marry. The play... follows the story of a large 
family as it gathers on the eve of the eldest daughter's wedding. The mother of the family has been driven literally crazy after being left by her husband after she gave birth to four girls and no boys. The oldest daughter works very hard to become a CEO amidst the guilt of not being born male, but deep inside she thirsts to be loved; the second daughter is looked down upon because of her frivolous attitude; the third submerges herself in books; while the youngest marries at a very young age in the hope of finding love in another family. The evening, which is supposed to be full of blessings and happiness, turns to a disaster for the family, after they are trapped together in the venue because of flooding. This is when the seething conflicts and differing natures that underlie their relationships start to unravel. "What I'm interested in is why a woman would still want to get married when she knows there is the possibility for divorce someday? What kind of man would she choose to marry? Where do her values, on which she bases her choice, come from?" said Wong Wing-sze, who wrote the play. Speaking of the play's title, Lam said, "Hatred emerges when love reaches extremes, so people who desperately want to get married probably also 'hate' marriage. "The word 'hate' implies that if a woman can't find a marriage partner, her worth will not be noticed or realized," said Lam. The situation comes from the pressures on single women when they reach the "proper" age for marriage, even if they have already achieved a lot in their career and other areas of their lives. (Global Times 2015-4-19, Love, Hate and Marriage).

These tensions are probably especially felt in relatively wealthy middle class families, where divorce is also stigmatized. During the Mao era welfare for individuals was provided by the work place. Now it is being privatized and increasingly costly for society and individuals. This probably puts considerable pressure on especially women to provide care and welfare for both children and parents-both their own and first of all those of their husbands. The Chinese "unprecedented materialistic advancement" might together with the retraditionalization of gender relations be seen as a curse for some women. The so-called "core socialist values" which were celebrated on Labour Day, May 1st, during my visit, are not surprisingly under strong pressure also in a professed "socialist market economy." Trust is in short supply in many relations-probably including in gender relations. Spouses avoid divorce and instead live apart or live with the presence of mistresses and lovers. To my surprise, very few people knew anything about divorce statistics, and I was not able to get reliable statistics about the divorce rate in China during my stay-in spite of good contacts with demographers. In a society almost obsessed with stability, instability and divorce in family life seemingly may become a sensitive issue. Greenland is 
seeing slightly higher divorce rates recently, as family structures are becoming 'modernized'. Women have a higher say in families due to economic income and higher educational levels. They also have a higher political representation under Home and Self Rule, where especially white men have been "defeated" politically. But in a market society and market culture it is again becoming clear that the dominant actors in business life and international investment are still white men, as aptly demonstrated in an extensive English language magazine on investment in Greenland on Air Greenland in February 2015. Hardly any women or Greenlandic men were featured.

\section{Kaassassuk - and other monsters?}

Greenlandic women are not under as strong a pressure as Chinese women to marry, and they have a considerably bigger say in terms of sexuality. But young women are often expected to get pregnant and have children early. They do not count on the relations to fathers of the children to last. As in China the family has always been a source of support, which is however weakened due to urbanization and longer distances between family members. At the same time the Nordic style welfare state is waning due to economic pressure. Some of the young female students I spoke to voiced their hesitation towards establishing a family. They had heard and read a lot about failed families and mistreated children who were not cared for, and for the time being they avoided having children in order not to neglect them. A researcher in gender and social welfare said that the present conditions in Greenland was reminiscent of descriptions of social change in post-communist and war affected societies in relation to violence and gender relations. It is well-known that men-and especially young men-have suffered from very high levels of suicide all over the Arctic. Orphans here as elsewhere have historically always been in a very vulnerable situation. An important example of this is the story of Kaassassuk, which was used by the Home Rule government in the beginning of the $21^{\text {st }}$ century as a symbolic orientation for the fight for more self-rule.

Kaassassuk is an orphan, who moves from family to family because nobody can cope with him. He is sick, he cannot keep food in his stomach and can't control his urine and stools. He doesn't grow. Finally his maternal grandmother takes care of him. The paternal grandmother rejects him. He is harassed by children and grown-ups, who lift him into the snow hut in his nostrils. He is given food so difficult to chew that he can hardly eat. He is then told to contact a super-natural force in the inland, which is called The Possessor of Strength, or the Master of Power, sometimes presented as a mixture 
of a huge fox-like creature with a human face. After a couple of meetings, the boy has gained sufficient strength to carry out great deeds. This new gained strength must not be revealed to others immediately. During the night, when nobody sees it the boy removes a big log of driftwood or an umiak (a women's boat). Later three polar bears turn up. Kaassassuk asks his grandmother to borrow him her kamiks, because he does not have any himself. He runs off, mocked by everybody, kills the bears, throws out the baby polar bear to the rest of the settlement, following the rules of sharing food, and brings back the rest to his grandmother to be used for meat and fur for clothing. From now on ridicule changes to fear. His enormous strength makes his fellows in the settlement follow his smallest wish. Soon the humiliated orphan turns into a brutal avenger. He starts hugging and then choking the small girls, who bring him water, and he continues humiliating and later killing former persecutors and tormentors. $^{3}$

There are many versions and interpretations of this story, and my outline above relates to one of the early ones. Later versions influenced by Christianity tend to have "softer" endings. In my abbreviation of this version Kassassuk turns into a monster. But the myth can clearly be understood as a cautionary tale warning listeners and readers to take care of the weak, the small and the vulnerable, as they may otherwise ally with super-natural forces and turn into tyrants and against their former oppressors. The myth can also be interpreted as a kind of David and Goliath story, where the small David defeats the grand Goliath. With this interpretation the sympathy of the audience will mostly go to David-the small and subdued. This was the background for the use of an image from the myth representing the fox-like Master of Power as a logo for the reports of the Self Rule Committee before 2009.

Arctic communities fear that sons, lovers, friends and other young men may suddenly commit suicide or that they may turn into uncontrollable monsters. China is according to a short study on the future implications of China's gender imbalance the only country in the world in which the suicide rate among women is higher than among men. Chinese families fear that "over-educated" women may be left-over, and the Chinese One Party State fears that young highly educated but underemployed young people-the socalled "ants" who live under ghastly conditions-may at some point become a threat to political stability. All of these fears probably relate to significant changes and instability in economic, social, political and gender relations. Similarly Europe and Western societies have come to fear young males-first

\footnotetext{
${ }^{3}$ This resumé is my own. I have included two different versions of the Kassassuk myth in my book Retspluralisme $i$ praksis. Grønlandske inspirationer. (2006)
} 
and foremost Muslim fundamentalists and terrorists, but also the sorts of Breivik, and the many, many school shooters primarily in the US. Does this indicate the violent consequences of "left-over" men in many parts of the world?

\section{Creative assimilation?}

In the Lu Xun Park in Shanghai one early Sunday morning in May 2015 I witnessed a lively show of mainly middle aged and older people dancing, fencing, practicing Tai Chi and Qi Gong. There were probably thousands of people. Later in the morning a crowd of a similar size would seemingly spontaneously team up and sing songs which were clearly well known to the big chorus directed by a volunteer director. The noisy amusement park for children attracted grandparents, parents and the highly revered grandchildren. Somehow it felt like a breathing place in a stark urban and commercialized culture. Lu Xun (1881-1936) was a favorite author of Mao and highly influential during the Mao era, I learnt later (Hua 2012). On the surface of a low wall was written in golden Chinese signs and latin letters THE WORLD LITERARY GIANT SQUARE. There were bronze sculptures of ten of these literary giants in front of the wall, which people used as pegs for their bags, and other stuff they could not carry while dancing, fencing, singing. These were the literary giants: Dante (1265-1321); Shakespeare (1564-1616); Goethe (1749-1832); Pushkin (1799-1837); Balzac (1799-1-850); Victor Hugo (1802-1885); Dickens (1812-1870); Tolstoy (1828-1910); R. Tagore (1861-1941); M. Gorki (1868-1938). All were male, most lived before the $20^{\text {th }}$ century, and most were from the so-called Western world.

I came across the concept of creative assimilation at some point in the beginning of this century, as a concept used by the Cuban author, José Lezama Lima, to describe the situation of writers of the Americas. I read his fantastic baroque novel Paradiso (originally from 1966) during a visit to Cuba with all of my family after Christmas in 2004-the year of the Tsunami in Asia. Gustavo Pellon (1989), whose intention is to study Lezama's role in world literature, writes that "(A)s participants in European culture only through the illegitimate inheritance of colonization, American writers are, in Lezama's view, free to partake of any cultural tradition that attracts them without committing themselves." I remember from other articles about Lezama that his idea was that all world literature would be part of a common heritage available to everybody-that humans would not be limited to their local or national literature, but be part of a tradition of world literature and cultural heritage.

Since the enactment of the Monroe Doctrine in 1823 the then United States of America considered Greenland as belonging to the US sphere of interest. 
The traditional and transnational Inuit culture has a home both in Russia, Alaska, Canada and Greenland. One may say that much of the Arctic culture has also taken the liberty to partake in the cultural traditions that attract them. The freedom to draw upon other traditions beyond one's closest and to re-cycle them may have a liberating effect on much of the world. Lezama was trained as a lawyer, he was gay, and he was an eclectic reader and lover of literature. In a no longer accessible online encyclopedia of gay, lesbian, bi-sexual, trans-gender \& queer culture a longer article by professor of literature Francisco Soto states that: "Internationally, the novel [Paradiso]was immediately recognized as a masterpiece. However, the novel's total lack of political commitment to the Cuban Revolution, as well as its explicit descriptions of male homosexual relations, was met with resistance in Cuba and placed Lezama in a precarious situation. As early as 1965, the new Cuban socialist regime had been conducting systematic purges of homosexuals whose conduct was considered to be at variance with revolutionary morals."

In 2014 a young female Greenlandic author, Niviaq Korneliussen, published a novel called HOMO Sapienne in Greenlandic and translated it herself into Danish. In the Danish version the five chapters have the following names: Crimson \& Clover-FIA; Home-INUK; Walk of ShameARNAQ; Stay-IVIK; What a Day-SARA. The words in capitalized letters are names of the shifting protagonists, who feature in the specific chapters-they are all interlinked as siblings, friends, foes and lovers, as well as linked via the music (videos) indicated in the first part of the names of the chapters. Homosexuality features prominently in the lives of the protagonists, who are gay, transsexual, bisexual and lesbians (Korneliussen 2014). Young people in Greenland speak a mixture of Greenlandic, Danish and English and are strongly influenced by North American and European culture. The texts are peculiarly decontextualized or perhaps globalized even if the novel takes place in Nuuk, Greenland. The author claims that she is writing a realist novel in terms of its focus upon individual problems, but she is not writing social realism, focusing upon problems of alcoholism and incest or upon the role of nature very often associated with and described in contemporary novels about and from Greenland. The novel may relate to a globalized adolescent identity in a world of text message communicationalso presented in the novel and in a world of changing gender identities, where heteronormativity seems to be slowly losing its monopoly-at least in some subcultures. This process of dissolution and change of gender norms has been viewed with anxiety all over for a long period, and still is in many parts of the world. Paradoxically the return of gender stereotypes seems to go hand in hand with their dissolution in many cultures. 
On the eve of International Women's Day March 8, 2015, five young Chinese feminists from Beijing and Guangzhou in southern China were detained by the authorities on suspicion of "picking quarrels and provoking trouble” (Zeng 2015). They were seemingly planning a multi-city protest aimed at bringing an end to sexual harassment on public transportation (similar to activities in Cairo after the Arab Spring). Some of them were part of the Chinese LGBT-movement, and they had often protested by way of performances as well as by using the censored Chinese internet. They belong to a post-Tien An Men generation, who may not feel so traumatized by that "event" even if (or because?) the memory of it has been strongly repressed in China. They were released on bail on April 13, 2015 but stayed under constant surveillance. I had several conversations with Chinese people about these young women, trying to understand how they would come to present a threat to a seemingly strong One Party State. Why would such a feminist action be considered more "political" than those of environmental activists? A professor who had worked with victims of pollution for several years claimed that feminism was considered more political than environmentalism by the government. Perhaps this was due to government fear of foreign funding and foreign revolutions such as the Orange Revolution in Ukraine, the Jasmine Revolution (or Arab Spring), a Sunflower movement by students in Taiwan and the student movement in Hong Kong. I heard reactions describing a return to a traditional gender culture and questions asking whether China was seeing an anti-feminist return to "core family values" similar to the religious "right" in US/Europe that is questioning women's empowerment/right. I also experienced young (male) lawyers, who had never heard about the case express disbelief that people would be detained for something like this.

A woman with closer knowledge of the Feminist Five described the context in this way:

Gender issues have become politicized. The ACWF (All China Women's Federation) stood for a form of 'national feminism' from 1949. After the Cultural Revolution in 1978 and in the 80s there was some debate on women's issues. What was better-a good husband or a good job. They did not emphasize gender differences before 1979 . The discussion on the commercialization of women's bodies started in the late 80s. The late 90s saw spreading feminist issues. From 19952005 most women were not really involved in women's rights. The majority of women in China were not involved. Women become more marginalized during the economic globalization. Women's strategies changed over the last 5 years-now there are educated activists in grassroots movements. The Feminist Five (age between 25-30) are well educated, well trained, educating and doing 
grassroots work all over the country-several of them are in the LGBTmovement. They focus on national laws, cases, implementation and education. College entrance exams require higher marks from women (a direct discrimination). They look at state accountability. (Quote from anonymous interviewee.)

In 2002 women's representation increased from 19 percent to 36 percent in Greenlandic parliament. A women's party “Arnat partiiat” had participated for the first and so far only time. The party did not get elected, but it succeeded in calling attention to different aspects of gender inequalities and not least to the lack of female candidates in the different parties (Poppel 2015). The establishment of the party was inspired by discussions before the establishment of Nunavut in the late 1990s about a female quota among the representatives, which were rejected at a local referendum. The LGBTmovement is quite recent and very internationalized both in China and in Greenland. However it may seem to present less of a direct challenge and threat to Greenlandic Self-Rule government, which is already strongly influenced by Western culture than to the One Party Chinese state. Perhaps both indigenous people and many women around the world have become more marginalized during economic globalization and thus feel less threatened by other marginalized movements and more prone to political action?

During my visit to Greenland in February 2015 passengers on several transatlantic flights were stuck for two nights in Kangerlussuaq, the international airport originally built as an American military base in another geopolitical era. The reason was as always rough weather in the coastal cities, but this time also very instable weather in Kangerlussuaq itself. Originally the place was chosen for a site for a military airport because of its constancy of weather conditions, now reduced in the era of climate change. The involuntary intermission gave me the opportunity to speak to several Greenlandic politicians, who were also trapped. A female politician spoke of the problem (!) of Greenland having too many highly educated women, and a former prime minister was very concerned that Greenland should not "sell itself too cheaply" when he spoke about the Chinese interest in investments in Greenland. In his view the Chinese were concerned about image in this respect. He and other Greenlanders I spoke to found Chinese people very agreeable, but he feared this might become a pretext for doing nothing. He was also very interested in knowing more about Chinese policies of collaboration and Chinese morality. Concerns about selling oneself to the highest bidder may be part of a process of assimilation to a global market culture not only for indigenous people but for many other groups around the world. Not least in a situation where young people have a future of precarious jobs and under- or unemployment to look forward to. 
Will (gender) justice and morality be considered as important as in a globalized and commercialized world-in the Arctic and elsewhere, as stability, harmony and security in some form?

\section{Postlude - Chinese and Arctic Dreams?}

One of my early culture shocks when I moved to Greenland was to be asked by a female student at a Christmas party, what I thought about dreams. I was baffled, and did not know what to answer. I hadn't been particularly interested in Freudian and Jungian dream analysis, and nobody discussed dreams in my professional environment. Not so in Greenland. In winter my students would show up and discuss their dreams and interpret them, politicians would refer to them in their speeches in Parliament, and talk about them in the meetings in one of the sub-committees on Self-Rule, where I was a member for a period. I began studying this phenomenon (Petersen 2006).

A female politician and member of parliament Asii Narup, who has for several election periods been and in 2017 still is a mayor in Greenland's most populous municipality, which includes the capital, Nuuk, wrote in an article in 1991:

I think that all humans are full of aspirations-dreams-fantasies and visions about our personal lives, about the lives we live with and in our families, and about the lives we live in common with all of society. I think that dreams and visions have their roots in strong wishes for improvements both for ourselves and others, and fundamentally express the will to create a better life. They are a resource-they are the ones, who "move the world." Not as long as we keep them to ourselves, but the moment they are declared and made a subject of discussion with others and later transformed into collective actions. (Narup 1991)

Present Greenlandic dreams are most likely diverse as elsewhere in the world. The first female Greenlandic prime minister clearly dreamt of an autonomous Greenland "independent" of Denmark-perhaps as a result of the strong Greenlandic focus during the last half century on political reform-and linked to the hopes of a mining economy due to amongst others Chinese demand. Some dreams may seem as nightmares to others as visualized in the dark paintings of Bolatta Silis Høegh. How will people in a globalized Arctic get a better life in an interdependent world?

French presidents tend to have museums built as mausoleums for their time in office, when they step back. In 2006 Musée du Quai Branly opened to celebrate President Jacques Chirac. It features indigenous art and 
cultures of Africa, Asia, Oceania, and the Americas-which means that both Inuit and Asian including some Chinese art is to be found in this meandering building. Recent Chinese presidents use slogans as their tools of direction, and the tool of former president $\mathrm{Hu}$ Jintao was the Confucian concept of harmony. Countless articles events etc. relating to harmony were produced, amongst them a book on human rights and harmony, which included an article on "Women's Rights and a Harmonious World" (Xiaolin Zhang 2007). A female European Human Rights worker in China described the government approach as "fake harmony", producing a "moral straitjacket". In Greenland another Greenlandic-Danish artist, Julie Edel Hardenberg, has used photographs of the Greenlandic and Danish flag-sown as physical strait jackets and called them "A Break from the Danish Realm". Is globalization producing a feeling of being locked up in a straitjacket, no matter whether it takes the form of economic or political reform?

The slogan of the present president Xi Jinping is "The Chinese Dream". Xi began promoting the phrase as a slogan in a high-profile visit to the National Museum of China in November 2012 after taking the office of general secretary of the Communist Party. It has become an ever more important slogan since 2013. In 2015 a lot of posters in Chinese cities portrayed images and texts about this dream. Exhibitions and discussions have taken place at all levels in society not least in primary schools and universities. It has been proclaimed as a guiding principle for the policy of the present government. Wikipedia writes that "The China Dream has been defined as sustainable development. Peggy Liu and the NGO JUCCCE coined the phrase "China Dream" as a movement based on sustainability, which was later popularized in China through a New York Times article and adopted by Xi Jinping."

Peggy Liu wrote in June 2012 in The Guardian

I lead a non-profit JUCCCE that seeks to accelerate China's sustainable development. Together with partners around the world, we're promoting a new, aspirational lifestyle called the China dream. The China dream realigns success with a healthy and fulfilling way of life - living more, rather than just having more. It promotes a sustainable lifestyle, but is not explicitly green. It offers a compelling alternative to the American dream that enshrines conspicuous consumption. The movement is not a moral-imperative campaign with rational arguments for energy savings; it offers a way of life that taps into consumers' desires and aspirations.

As with the myth of Kaassassuk the myth of the Chinese Dream can and will be interpreted in many as well as conflicting and competing ways. However, some of these dreams and some of their interpretations may not be as far away from each other as one might think in this inter-dependent world 
developing towards new geo-political landscapes and often unbalanced relations. It may take considerable efforts by both small sparrows and monster birds to realize such fuzzy dreams.

\section{Acknowledgements and funding}

I would like to thank Ilisimatusarfik, University of Greenland for cofinancing a research trip to Nuuk in February 2015, and Sino-Danish Center (SDC) for financing a research trip to China in April-May 2015. These trips produced invaluable material for this article. I also owe a debt to many colleagues and interview partners in both Denmark and China for their help, informations and contributions in this research process. My writing of this article was amongst others also inspired by Phillip Lopate's book To Show and To Tell. The Craft of Literary Nonfiction, 2013.

\section{References}

Arnfred, Signe. 1991. Kvinder, mænd, arbejde og seksualitet i den grønlandske moderniseringsproces. In Lise Lennert, Johanne Petrussen, Signe Arnfred and Marianne Lykke Thomsen. Kvinder i Grønland sammen og hver for sig. [Women in Greenland. Together and on their own]. Nuuk: Atuakkiorfik.

Bjerregaard, Peter. (ed.). 2001. Abort i Grønland. In INUSSUK, Arktisk Forskningsjournal 2

http://naalakkersuisut.gl/ /media/Nanoq/Files/Publications/Uddannelse /Abort i Grønland.pdf (Accessed 2017-06-04).

Degeorges, Damien. 2013. Denmark, Greenland and the Arctic. Challenges and opportunities of becoming the meeting place of global powers. Copenhagen: Royal Danish Defense College Publishing House. http://www.fak.dk/publikationer/Documents/Denmark-Greenland-andthe-Arctic.pdf (Accessed 2017-06-04).

Fearon, Tom. 2015. Clearing the Air. The smog (probably) won't worry you until you have kids. Beijing Parents and Kids. 9 April-7 May.

Fox-Lerner, Aaron. 2015. Breaking the Barrier: Translating Under the Dome: How two Beijing Students Brought the Film to the World's Attention.

Time Out Beijing. 8

April. http://www.timeoutbeijing.com/features/Books_Film-

Film_Features/37710/Breaking-the-barrier-translating-Under-theDome.html (Accessed 2017-06-04).

Hua, Yu. 2012. China in Ten Words. (People; Leader; Reading; Writing; Lu Xun; Revolution; Disparity; Grassroots; Copycat; Bamboozle). New York: Anchor Books. 
I CHING or book of changes. (1951/1989). The Richard Wilhelm translation. Rendered into English by Cary F. Baynes. With a foreword by C.G. Jung. London: Arkana.

Korneliussen, Niviaq. 2014. HOMO Sapienne. Nuuk: Milik Publishing. Lezama Lima, José. 1968/2000. Paradiso (translated by Gregory Rabassa). Mclean, IL: Dalkey Archive Press.

Liu, Peggy. 2012. China dream: a lifestyle movement with sustainability at its heart. The Guardian. 13 June.

Lopate, Phillip. 2013. To Show and to Tell. The Craft of Literary Nonfiction. New York, London, Toronto, Sydney, New Delhi: Free Press (Kindle version).

McCoy, Alfred W. 2015. The Geopolitics of American Global Decline: Washington Versus China in the Twenty-First Century. http://www.tomdispatch.com/post/176007/tomgram\%3A_alfred_mccoy \%2C_washington\%27s_great_game_and_why_it\%27s_failing_/\#more (Accessed 2017-08-14).

Moïsi, Dominique. 2009. The Geopolitics of Emotion: How Cultures of Fear, Humiliation, and Hope are Reshaping the World. Doubleday: New York.

Narup, Asii. 1991. Om at gøre drømme til virkelighed. In Lise Lennert, Johanne Petrussen, Signe Arnfred and Marianne Lykke Thomsen. Kvinder i Grønland - sammen og hver for sig. [Women in Greenland. Together and on their own]. Nuuk: Atuakkiorfik.

Nordlund, Mads. 2014. Art That Means Something. (In Danish and English). (On Artist Bolatta Silis Høegh). Greenland Today. Worldwide Magazine. http://greenlandtoday.com/bolatta-silis-hoeegh/ (Accessed 2017-06-04).

Osnos, Evan. 2014. The Age of Ambition: chasing fortune, truth, and faith in the new China. New York: Farrar, Straus and Giroux.

Pellon, Gustave. 1989. José Lezama Lima's Joyful Vision: A Study of Paradiso and Other Prose Works. Austin: University of Texas Press

Petersen, Hanne. 1996. Home Knitted Law. Norms and Values in Gendered Rule-Making. Dartmouth: Dartmouth Publishing Group.

Petersen, Hanne. 2006. Retspluralisme i praksis-grønlandske inspirationer. (Legal Pluralism in practice-Greenlandic inspirations) [Ch. 17: Drømme og fællesskaber-forholdet mellem Grønland og Danmark ved årtusindskiftet. /Dreams and communities-the relation between Greenland and Denmark at the change of the millennium]. Copenhagen: Ilisimatusarfik \& Jurist- og Økonomforbundets Forlag.

Petersen, Hanne. 2011. Justice, Benevolence, and Happiness: Encounter and Challenges in Global Legal Culture. In Michal Tomášek and Guido Mühlemann (eds.). Interpretation of Law in China-Roots and Perspectives. Charles University in Prague. Prague: Karolinum Press, 11-20. 
Petersen, Hanne. 2014a. Sociology of Law at "the Edge of Empires and Eras": Reflections on Lawyers and Living Law 65 Years after the Legal Expedition to Greenland.” In Knut Papendorf, Stefan Machura and Anne Hellum (eds.). Eugen Ehrlich's Sociology of Law. Vol. 8. Berlin: LIT Verlag Dr. Wilhelm Hopf, 133-153.

Petersen, Hanne. 2014b. Demokratiske stemmer og visioner: før og nu. [Democratic Voices and Visions: Before and Now] In Helle Krunke, Jens Elo Rytter, Jørn Vestergaard, Kristian Lauta and Peter Blume (eds.). Rettens Magt - Magtens Ret: Festskrift til Henning Koch. Copenhagen: DJØF Publishing, 309-319.

Petersen, Hanne. 2015. Reconstituting Orders after Neo-Liberalism? The "Growth Fetish", Gender and Environment in Sino-European Interchanges. Women, Gender \& Research 1, Special Issue: Gender Dynamics. Chinese-Nordic Perspectives: 134-143.

Poppel, Mariekathrine. 2015. Changes in gender roles in Greenland and perceived contributions to the household. In SLiCA: Arctic living conditions: Living conditions and quality of life among Inuit, Saami and indigenous peoples of Chukotka and the Kola Peninsula. Copenhagen: Nordisk Ministerråd, 297-318.

Schaffer, Kay and Smith, Sidonie. 2014. E-Witnessing in the Digital Age. In Meg Jensen and Margaretta Jolly (eds.). We Shall Bear Witness. Life Narratives and Human Rights. Madison: University of Wisconsin Press, 223-237.

Schultz-Lorentzen, Christian. 2014. Bolatta Silis-Høegh: Første gang jeg skammer mig over at være grønlænder. Sermitsiaq/AG (Bilingual Greenlandic Newspaper). 10 August.

Smith, Lawrence C. 2012. The New North. The World in 2050. London: Profile Books.

Statistics Greenland. 2014. Greenland in Figures 2014. 11th revised edition. http://www.stat.gl/publ/da/GF/2014/pdf/Greenland\%20in\%20Figures\%2 02014.pdf (Accessed 2017-06-04).

Vahl, Katja. 2014. Et nøgent nej til uran. (Article about Bolatta Silis Høegh). Arnanut (Bilingual Greenlandic Women's Magazine) Winter, no. 46.

Zeng, Jinyan, 2015. China's feminist five: 'This is the worst crackdown on lawyers, activists and scholars in decades'. The Guardian. 17 April.

Zhang, Xiaoling. 2007. Women's Rights and a Harmonious World. In Dong Yunhu, Chen Zhengong and Wang Linxia (editors in chief). Human Rights and Harmonious World. Beijing: TjPress, 100-111. 


\section{Websites:}

http://bolatta.com/about homepage for Bolatta Silis Høegh. 2017 (Accessed 2017-05-29)

Jing, Chai. 2015. Under the Dome - Documentary on China's Pollution. Part 1-8. [online]. YouTube Videos.

https://www.youtube.com/watch?v=MhIZ50HKIp0 (Accessed 2017-0529).

The Global Arctic Project. (no date). http://www.globalarctic.org (Accessed 2017-05-29).

Global Times. 2015. Love, Hate, and Marriage. http://www.globaltimes.cn/content/917526.shtml (Accessed 2017-05-29).

Under the Dome (film). Wikipedia.

https://en.wikipedia.org/wiki/Under_the_Dome_(film) (Accessed 2017-0529).

Whitman, Walt. 1871. Democratic Vistas.

http://xroads.virginia.edu/ hyper/Whitman/vistas/vistas.html (Accessed 2017-06-04).

\section{Notes on contributor}

Hanne Petersen, Dr. jur. 1991, Professor of legal cultures at the University of Copenhagen since 2009. She was Jean Monnet Scholar at EUI in Florence 1993-94; professor of jurisprudence and sociology of law at University of Greenland, Ilisimatusarfik 1995-99, and professor of Greenlandic sociology of law at UofCph 2001-2006. She has held several Nordic guest professorships (now in Gothenburg) and was a member of the Danish Equality Board from 2009-2015. She has worked with issues concerning China since 2009. 